\title{
Nitrogen budget of Lago Maggiore: the relative importance of atmospheric deposition and catchment sources
}

\author{
Rosario MOSELLO*, Alberto BARBIERI ${ }^{1)}$, Maria Cristina BRIZZIO, Alcide CALDERONI, \\ Aldo MARCHETTO, Stefania PASSERA, Michela ROGORA and Gabriele TARTARI \\ C.N.R. Istituto Italiano di Idrobiologia, L.go Tonolli 50, 28922 Verbania Pallanza, Italy \\ ${ }^{1)}$ Laboratorio Studi Ambientali, Sezione Protezione Aria e Acqua, Lugano Paradiso, Canton Ticino, Switzerland \\ *e-mail corresponding author: r.mosello@iii.to.cnr.it
}

\begin{abstract}
Hydrological and chemical data of 1996 and 1997 are used to evaluate the relative contributions of atmospheric deposition and urban/industrial wastewaters to the nitrogen budget of Lago Maggiore. The atmospheric load of nitrogen was about $80 \%$ of the total input to the lake, with negligible variations in dry (1997) and wet (1996) years. A comparison of the two study years with the yearly $N$ budgets evaluated from 1978 to 1998, showed that the $N$ load was higher with increasing amounts of precipitation/water inflow. Soils and vegetation act as $N$ sinks; the \% retention varies between 40-60\% for the forested catchments with low population density in the central-northern part of the basin, to values close to zero or even negative in the south, indicating a net leaching from the soils. The Traaen \& Stoddard (1995) approach revealed that all the catchments of the major inflowing rivers were oversaturated with nitrogen. The long-term trend of nitrogen concentrations in Lago Maggiore (1955-99) is analogous to the trend for atmospheric deposition (1975-99), which is related to emissions of nitrogen oxides and ammonia in the atmosphere. The relationships between the present $N$ load and in-lake concentrations are discussed using a budget model, which is also used to infer the pristine load of $N$. The close relationships between $N$ trends in lakes Maggiore, Como and Iseo, and the geographical and anthropogenic features common to their catchments, suggest that the results obtained for Lago Maggiore can be extended to a wider area.
\end{abstract}

Key words: Lago Maggiore, nitrogen budget, atmospheric deposition, river water, catchment

\section{INTRODUCTION}

Nitrate and ammonium are important components in the atmospheric deposition of Northern Italy, together constituting on average $30-50 \%$ of the total ionic composition. Nitrogen compounds are much more involved than sulphur in biological processes within ecosystems. After reaching the soil, they can be transformed chemically and biologically, and taken up by plants and micro-organisms. Nitrogen is a growth-limiting nutrient in many terrestrial ecosystems. Together with phosphorus, it is the most important factor limiting algal growth in natural waters, and so may contribute to eutrophication processes, especially in nitrogen-limited water bodies, in coastal areas in particular (Paerl \& Whitall 1999; Tyrell 1999). Long-term atmospheric deposition and other anthropogenic sources may lead to a situation where the availability of inorganic nitrogen is far in excess of the total amount required for plant and micro-organism growth. Nitrogen saturation for a catchment is defined as a persistent loss of nitrate and ammonium in streamflow or groundwater discharge which may be accompanied by increases in nitrogen mineralization and nitrification in the soil (Aber et al. 1989). Traaen \& Stoddard (1995) classify different stages of saturation in catchments by considering seasonal variations in nitrate leaching.
Nitrate is involved in surface water and soil acidification processes. Nitrate leaving a catchment contributes to soil acidification by removing base cations from the soil, and to water acidification by mobilising aluminium and hydrogen ions. Due to decreases in sulphate deposition in Europe and North America since 1980, the relative importance of nitrogen in acidification is increasing. A widespread decrease of sulphate concentrations in surface waters was observed in many European and North American sites in the 1980s and 1990s, as a consequence of the decline in sulphur deposition due to successful emission reduction measures (Stoddard et al. 1999). In contrast, nitrate concentrations remained constant or even increased in the 1990s (Lükewille et al. 1997; Stoddard et al. 1999).

Northern Italy is characterised by high deposition of atmospheric pollutants and high concentrations of nitrogen compounds in rainwater. Previous studies dealt with the long-term trends of nitrogen, sulphate and acidity deposition in the region; the Lago Maggiore catchment in particular has been studied in detail (Mosello et al. 1993a; 2000a; Marchetto et al. 1998). The catchment covers an area of about $6600 \mathrm{~km}^{2}$ (Fig. 1), and receives a high amount of orographic precipitation and deposition of pollutants. The lake is located in the foothills of the Alps, just north of the most industrialised part of Italy, which includes cities such as Milan and Turin (Carollo et al. 1985). There have been various studies 


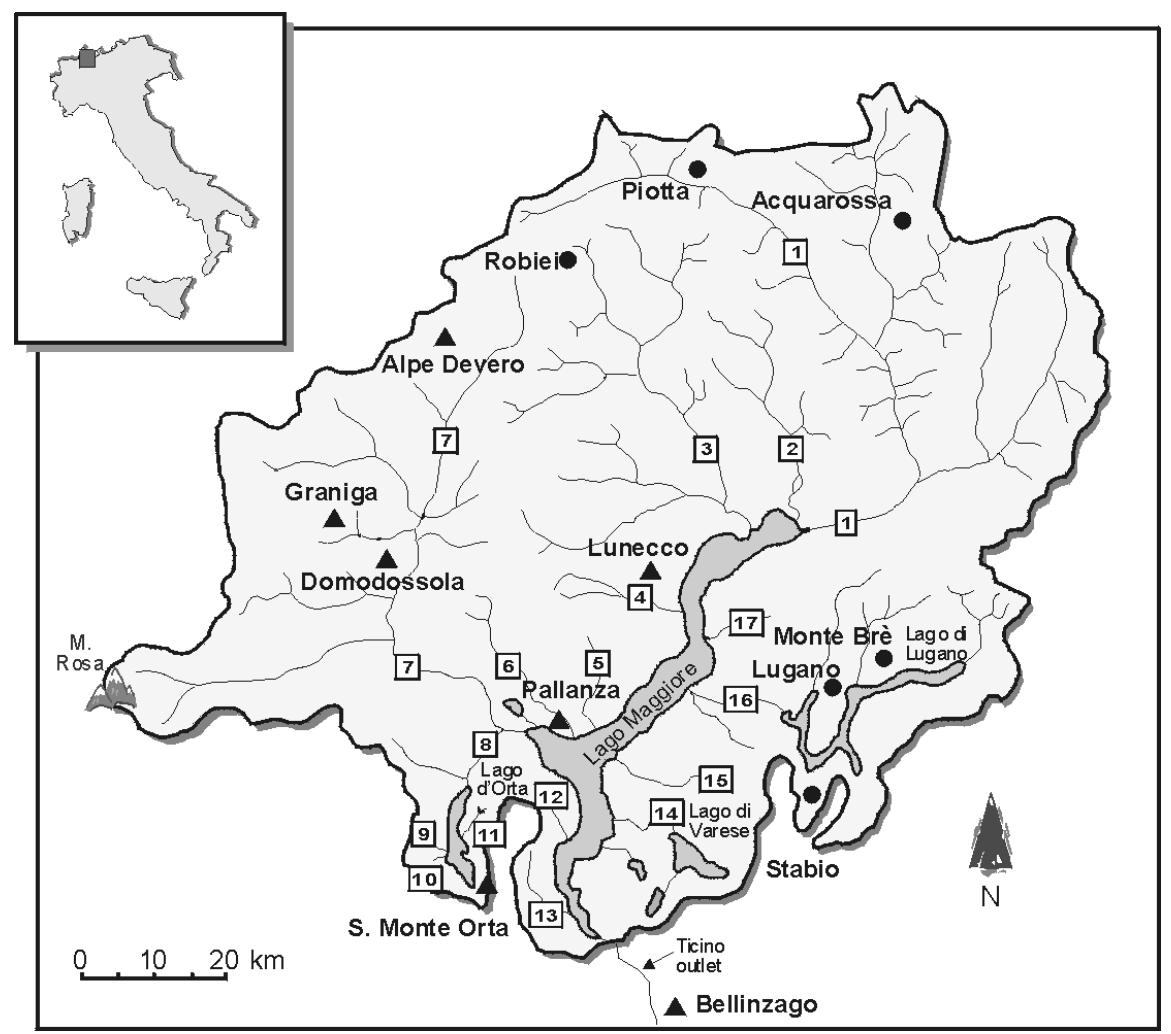

Fig. 1. Lago Maggiore catchment with the Italian $(\boldsymbol{\Delta})$ and Swiss $(\mathbf{O})$ atmospheric deposition sampling stations and the rivers considered (numbers refer to table 3 ).

on the long-term chemical evolution of streams and lakes both in the subalpine area (Mosello et al. 1993b; Boggero et al. 1996) and at high altitude in the Alps, where there are many water bodies sensitive to acidification (Mosello et al. 1993c; Marchetto et al. 1995). The trend in nitrate concentrations in the deep subalpine lakes (Maggiore, Como, Iseo) has been increasing during the last 40 years, and became more pronounced during the 1960s and 1970s (Mosello et al. 2000b; Ambrosetti et al. 1992). This increase was generally ascribed to urban and industrial wastewater inputs of both nitrogen and phosphorus. Several recent studies however have pointed out the prominent role played by atmospheric deposition as a nitrogen source in the Lago Maggiore catchment (Marchetto et al. 1998; Mosello et al. 2000a). The trends in $\mathrm{N}$ concentrations are similar in the deep lakes north of the Alps, which have morphometric and hydrologic characteristics close to those of Lago Maggiore (Mengis et al. 1997a).

The research presented in this paper was designed to measure the nitrogen budget of the Lago Maggiore catchment and to assess the relative importance of atmospheric deposition and urban/industrial wastewater inputs. Further aims were to evaluate the nitrogen saturation status of the catchment, and to explain the increase of nitrogen concentrations in the lake.

The chemical data for both atmospheric deposition and the Lago Maggiore tributaries presented in this pa- per refer to 1997 . We compare these results with those obtained in 1996, pointing out the marked interannual variability in the calculation of the total nitrogen budget. This feature was also discussed on the basis of data on the yearly nitrogen balance available for the twenty years from 1978 to 1998 , evaluated in the framework of studies performed on the eutrophication of Lago Maggiore (Mosello \& Ruggiu 1983; Calderoni \& Mosello 1989; Bertoni et al. 1998).

\section{STUDY AREA, SAMPLING AND METHODS}

The main morphometric characteristics of Lago Maggiore and its catchment are shown in table 1. The catchment $\left(6600 \mathrm{~km}^{2}\right)$ (Fig. 1) lies half in Italy (Piedmont and Lombardy) and half in Switzerland (Canton Ticino). The northernmost part of the area is occupied by the Alps, with the highest peak (Monte Rosa) 4633 $\mathrm{m}$ a.s.1.; most of the population $(634,000)$ lives in the subalpine area in the southern part of the catchment where the main industrial activities are also located. The morphological characteristics of the area do not permit extensive agriculture, so that the use of nitrogen fertilisers is negligible.

Thirteen sampling stations were used to measure the nitrogen input from atmospheric deposition, 7 in Italy and 6 in Switzerland (Fig. 1; Tab. 2). Sampling frequency was weekly, using wet-only collectors. Samples were analysed for precipitation amount and major 
chemical determinants: $\mathrm{pH}$, conductivity at $20^{\circ} \mathrm{C}$, alkalinity (acidimetric titration, Gran's method), ammonium (spectrophotometry, indophenol blue), base cations $\left(\mathrm{Ca}^{++}, \mathrm{Mg}^{++}, \mathrm{Na}^{+}, \mathrm{K}^{+}\right)$, and strong acid anions $\left(\mathrm{SO}_{4}{ }^{2}\right.$, $\mathrm{NO}_{3}^{-}, \mathrm{Cl}^{-}$) (ion chromatography). Intercalibration exercises performed by the Italian and Swiss laboratories show that the results are comparable (Mosello et al. 1998). The sampling station of Bellinzago is not in the Lago Maggiore catchment, but was included to give a more precise picture of the southern part of the study area.

Tab. 1. Main morphometric and hydrological characteristics of Lago Maggiore and its catchment.

\begin{tabular}{lcc}
\hline Mean watershed altitude & $\mathrm{m}$ a.s.l. & 1270 \\
Mean lake altitude & $\mathrm{m}$ a.s.l. & 194 \\
Watershed area (lake included) & $\mathrm{km}^{2}$ & 6599 \\
Lake area & $\mathrm{km}^{2}$ & 212.5 \\
Watershed/lake area ratio & & 31.1 \\
Mean depth & $\mathrm{m}$ & 177 \\
Maximum depth & $\mathrm{m}$ & 370 \\
Max breadth & $\mathrm{km}$ & 10.0 \\
Mean breadth & $\mathrm{km}$ & 3.9 \\
Shoreline length & $\mathrm{km}$ & 170 \\
Volume & $\mathrm{km}^{3}$ & 37.5 \\
Mean outflow discharge (1978-95) & $\mathrm{m}^{3} \mathrm{~s}^{-1}$ & 287 \\
Theoretical renewal time & years & 4 \\
\hline
\end{tabular}

Tab. 2. Geographical characteristics of the atmospheric deposition sampling stations.

\begin{tabular}{lcccc}
\hline & Country & $\begin{array}{c}\text { Alt. } \\
\text { (m a.s.1.) }\end{array}$ & Lat. N & Long. E \\
\hline Pallanza & Italy & 208 & $45^{\circ} 55^{\prime}$ & $8^{\circ} 34^{\prime}$ \\
Domodossola & Italy & 270 & $46^{\circ} 06^{\prime}$ & $8^{\circ} 12^{\prime}$ \\
Graniga & Italy & 1080 & $46^{\circ} 07^{\prime}$ & $8^{\circ} 11^{\prime}$ \\
Devero & Italy & 1634 & $46^{\circ} 19^{\prime}$ & $8^{\circ} 15^{\prime}$ \\
Lunecco & Italy & 415 & $46^{\circ} 04^{\prime}$ & $8^{\circ} 36^{\prime}$ \\
Bellinzago & Italy & 190 & $45^{\circ} 35^{\prime}$ & $8^{\circ} 40^{\prime}$ \\
Orta & Italy & 360 & $45^{\circ} 50^{\prime}$ & $8^{\circ} 25^{\prime}$ \\
Lugano & Switzerland & 350 & $46^{\circ} 00^{\prime}$ & $8^{\circ} 57^{\prime}$ \\
Piotta & Switzerland & 1007 & $46^{\circ} 31^{\prime}$ & $8^{\circ} 40^{\prime}$ \\
Acquarossa & Switzerland & 575 & $46^{\circ} 27^{\prime}$ & $8^{\circ} 56^{\prime}$ \\
Stabio & Switzerland & 353 & $45^{\circ} 51^{\prime}$ & $8^{\circ} 55^{\prime}$ \\
Robiei & Switzerland & 1890 & $46^{\circ} 26^{\prime}$ & $8^{\circ} 30^{\prime}$ \\
Monte Bré & Switzerland & 925 & $46^{\circ} 00^{\prime}$ & $8^{\circ} 59^{\prime}$ \\
\hline
\end{tabular}

The main tributaries of Lago Maggiore (Fig. 1) were sampled monthly, their flows measured and the loads for the main variables calculated (Mosello \& De Giuli 1982). The morphometric and hydrological characteristics of these rivers are shown in table 3. River samples were analysed for the same variables as rain samples and also for reactive and total phosphorus, total nitrogen and reactive silica. Further details on analytical methods and on quality controls are reported in Tartari \& Mosello (1997).

The spatial distribution of atmospheric deposition and river chemistry on the Lago Maggiore catchment was determined by the use of a Kriging method to interpolate the chemical data on the whole area.
The $\mathrm{N}$ budget was determined for each river catchment taking into account the atmospheric input of inorganic $\mathrm{N}\left(\mathrm{NH}_{4}^{+}+\mathrm{NO}_{3}^{-}\right)$to the catchments via wet deposition and the output of total $\mathrm{N}$ (including organic $\mathrm{N})$ from the catchments through the outflowing river waters.

The percent retention of nitrogen in each catchment is calculated as follows:

$$
\% \text { retention }=100 \times \frac{(\text { input }- \text { output })}{\text { input }}
$$

The inputs include atmospheric deposition and the contribution from the population; the input from agriculture was not considered. The outputs do not take into account other possible losses of nitrogen due to denitrification processes or to biomass removal.

The approach proposed by Traaen \& Stoddard (1995) was applied to some selected tributaries to classify the $\mathrm{N}$ saturation status for the various river catchments. This method is based on monthly-average nitrate concentrations, and interprets these in terms of seasonal vegetation cycles. It defines four different nitrogen saturation stages, corresponding to a hypothetical process which terrestrial ecosystems can go through if atmospheric nitrogen deposition remains high.

- Stage 0: the nitrogen cycle is dominated by forest and microbial uptake governing the seasonal nitrate pattern of runoff water; nitrate concentrations are very low during most of the year (more than 3 months in the growing season with $\mathrm{NO}_{3} \leq 3 \mu \mathrm{mol} l^{-1}$ and peak value $<20 \mu \mathrm{mol}^{-1}$ ).

- Stage 1: the switch from physical to nutrient limitation in spring is delayed. Substantial amounts of nitrate may leave the catchment during extreme hydrological events (1-2 months in the growing season with $\mathrm{NO}_{3} \leq 3 \mu \mathrm{mol} \mathrm{l} \mathrm{l}^{-1}$ or more than 3 months in the growing season with $\mathrm{NO}_{3} \leq 3 \mu \mathrm{mol} \mathrm{l} \mathrm{l}^{-1}$ and peak value $<20 \mu_{\mathrm{mol}}{ }^{-1}$ );

- Stage 2: the seasonal onset of nitrogen limitation is even further delayed so that biological demand no longer controls nitrate concentrations in winter and spring. The period of nitrogen limitation during the growing season is reduced (no month with $\mathrm{NO}_{3} \leq 3$ $\mu \mathrm{mol} \mathrm{l}{ }^{-1}$ and more than 3 months in the growing season with nitrate $\leq 50 \mu \mathrm{mol} \mathrm{l}^{-1}$ );

- Stage 3: there is no seasonal pattern to nitrate output. The mineralization of stored nitrogen can add substantially to nitrate output in surface waters which may, together with gaseous emissions $\left(\mathrm{N}_{2} \mathrm{O}\right)$, exceeds inputs from nitrogen deposition alone (less than 3 months with $\mathrm{NO}_{3}<50 \mu \mathrm{mol} \mathrm{l}^{-1}$ ).

The method is not applicable to catchments which receive inputs of $\mathrm{N}$ from agricultural, industrial or municipal activities within the catchment. For this reason, we selected a group of rivers in which these sources of nitrogen could be considered negligible. 
Tab. 3. Main morphometric characteristics of Lago Maggiore tributaries.

\begin{tabular}{|c|c|c|c|c|c|c|c|c|}
\hline & & $\begin{array}{l}\text { Max altitude } \\
\text { (m a.s.l.) }\end{array}$ & $\begin{array}{l}\text { Min altitude } \\
\text { (m a.s.1.) }\end{array}$ & $\begin{array}{l}\text { Mean altitude } \\
\quad(\mathrm{m} \text { a.s.1.) }\end{array}$ & $\begin{array}{l}\text { Length } \\
(\mathrm{km})\end{array}$ & $\begin{array}{l}\text { Catchment area } \\
\qquad\left(\mathrm{km}^{2}\right)\end{array}$ & $\begin{array}{l}\text { Area/Length } \\
(\mathrm{km})\end{array}$ & $\begin{array}{l}\text { Annual average discharge } \\
\qquad\left(\mathrm{m}^{3} \mathrm{~s}^{-1}\right)\end{array}$ \\
\hline 1 & Ticino inlet & 3402 & 193 & 1720 & 90 & 1616 & 17.9 & 66.9 \\
\hline 2 & Verzasca & 2864 & 193 & 1611 & 33 & 237 & 7.1 & - \\
\hline 3 & Maggia & 3273 & 193 & 1550 & 56 & 926 & 16.6 & 21.7 \\
\hline 4 & Cannobino & 2193 & 193 & 1057 & 27 & 110 & 4.1 & 5.9 \\
\hline 5 & S. Giovanni & 2156 & 193 & 914 & 18 & 61 & 3.5 & 2.5 \\
\hline 6 & S. Bernardino & 2301 & 193 & 1228 & 29 & 131 & 4.5 & 6.3 \\
\hline 7 & Toce & 4633 & 193 & 1570 & 80 & 1547 & 19.3 & 73.8 \\
\hline 8 & Strona & 2421 & 200 & 800 & 28 & 224 & 7.9 & - \\
\hline 9 & Pellino & 942 & 290 & 650 & 12 & 18 & 1.5 & 0.9 \\
\hline 10 & Pellesino & 1136 & 290 & 680 & 7 & 3 & 0.4 & 0.2 \\
\hline 11 & Pescone & 1491 & 290 & 1150 & 18 & 18 & 1.0 & 0.9 \\
\hline 12 & Erno & 1491 & 193 & 657 & 15 & 26 & 1.8 & 0.9 \\
\hline 13 & Vevera & 912 & 193 & 449 & 13 & 21 & 1.6 & 0.5 \\
\hline 14 & Bardello & 1227 & 193 & 284 & 23 & 134 & 5.8 & 2.9 \\
\hline 15 & Boesio & 1235 & 193 & 501 & 14 & 45 & 3.1 & 1.6 \\
\hline 16 & Tresa & 2245 & 193 & 650 & 58 & 754 & 13.0 & 24.3 \\
\hline 17 & Giona & 1962 & 193 & 998 & 14 & 50 & 3.5 & - \\
\hline
\end{tabular}

\section{RESULTS}

\subsection{Atmospheric deposition}

The monthly amounts of precipitation collected during the study period (1996 and 1997) at two stations, Domodossola and Pallanza, were compared with the historical mean (1972-95) (Fig. 2).

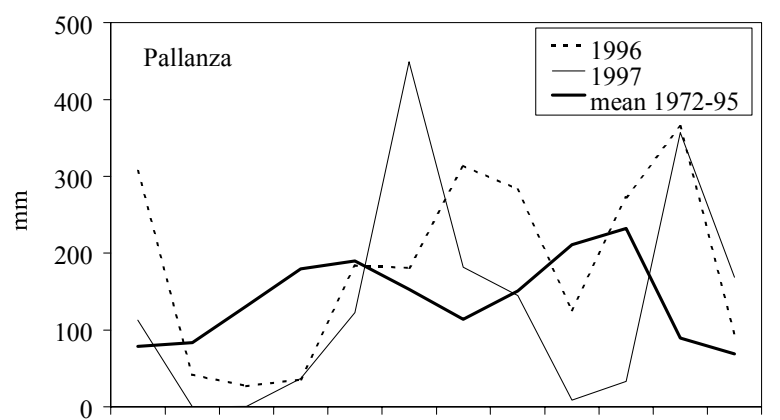

Jan Feb Mar Apr May Jun Jul Aug Sep Oct Nov Dec

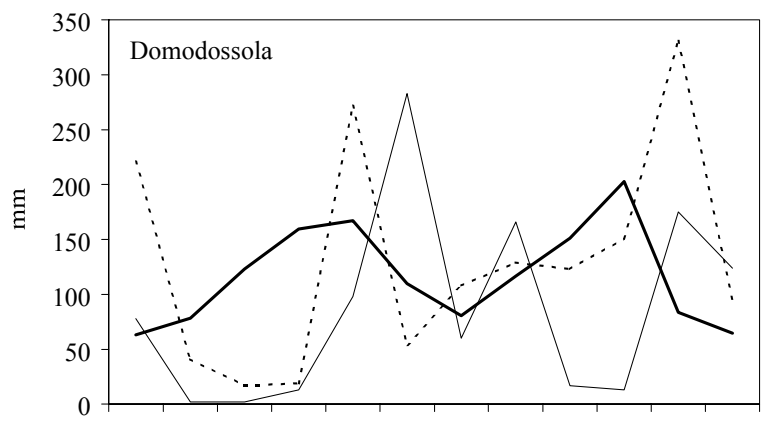

Jan Feb Mar Apr May Jun Jul Aug Sep Oct Nov Dec

Fig. 2. Monthly amount of deposition at Pallanza and Domodossola in 1996 and 1997 compared with the historical mean (1972-95).
For both stations in 1997 the June volumes were far above the mean value (283 $\mathrm{mm}$ versus $110 \mathrm{~mm}$ for Domodossola and $449 \mathrm{~mm}$ versus $150 \mathrm{~mm}$ for Pallanza). Other relative maxima were recorded in November and, only for Domodossola, in August, while the periods February-April and September-October were characterised by minimum volumes of precipitation $(0-20 \mathrm{~mm})$ in both stations. Taken as a whole, the total amount of precipitation is quite a lot higher in Pallanza (1600 mm) than in Domodossola (1030 mm). 1996 shows a similar pattern, with precipitation maxima in November and minima in March-April, but the total amounts (2230 and 1560 at Pallanza and Domodossola, respectively) are considerably higher than those measured in 1997.

We also considered the two years from the hydrological point of view, measuring the monthly outflow discharges of the Ticino outlet in 1996 and 1997 and plotting them against the historical mean of the period 1978-95 (Fig. 3).

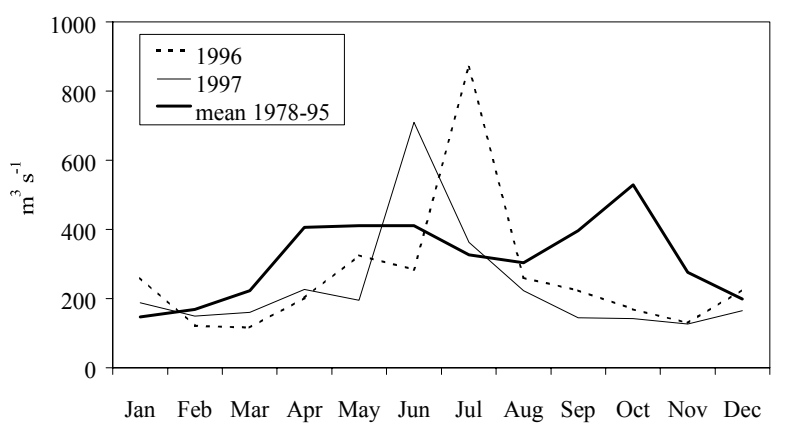

Fig. 3. Monthly outflow discharges of the Ticino outlet measured in 1996 and 1997 against the historical mean of the period 1978-95.

As a consequence of the high volume of precipitation in June 1997, the flow in this month was far above the mean value. The mean discharge was $232 \mathrm{~m}^{3} \mathrm{~s}^{-1}$, 
Tab. 4. Volume weighted mean values (1997) of the main chemical variables in the atmospheric depositions. Conductivity: $\mu \mathrm{S} \mathrm{cm}^{-1} 20^{\circ} \mathrm{C}$. Ionic concentrations in $\mu \mathrm{eq}^{-1}$. * calculated as volume weighted mean of the $\mathrm{H}^{+}$ concentrations.

\begin{tabular}{lcccccccccccccccc}
\hline & $\begin{array}{c}\text { Volume } \\
(\mathrm{mm})\end{array}$ & $\mathrm{pH}$ & Cond. & $\mathrm{H}^{+}$ & $\mathrm{NH}_{4}^{+} \mathrm{Ca}^{++}$ & $\mathrm{Mg}^{++}$ & $\mathrm{Na}^{+}$ & $\mathrm{K}^{+}$ & $\mathrm{Alk}$. & $\mathrm{SO}_{4}{ }^{*}$ & $\mathrm{NO}_{3}{ }^{-}$ & $\mathrm{Cl}^{-}$ & $\mathrm{Cations}$ & Anions & $\mathrm{Ions}$ \\
\hline Pallanza & 1547 & 4.54 & 22.5 & 29 & 53 & 13 & 3 & 8 & 2 & n.d. & 48 & 44 & 8 & 108 & 100 & 208 \\
Domodossola & 1168 & 4.71 & 14.2 & 19 & 29 & 10 & 2 & 6 & 1 & n.d. & 29 & 27 & 5 & 67 & 61 & 128 \\
Graniga & 1610 & 4.67 & 15.3 & 21 & 34 & 11 & 2 & 5 & 2 & n.d. & 32 & 29 & 6 & 75 & 67 & 142 \\
Devero & 1395 & 4.72 & 13.3 & 19 & 24 & 10 & 2 & 6 & 2 & n.d. & 23 & 26 & 6 & 63 & 55 & 118 \\
Lunecco & 1819 & 4.63 & 17.6 & 23 & 40 & 9 & 2 & 7 & 2 & n.d. & 37 & 35 & 7 & 84 & 79 & 163 \\
Bellinzago & 931 & 4.63 & 19.9 & 23 & 54 & 13 & 4 & 8 & 2 & n.d. & 45 & 43 & 9 & 105 & 97 & 202 \\
Orta & 1263 & 4.60 & 19.8 & 25 & 55 & 12 & 3 & 8 & 2 & n.d. & 45 & 47 & 9 & 106 & 101 & 207 \\
Lugano & 1191 & 4.91 & 16.0 & 12 & 43 & 19 & 7 & 8 & 2 & 2 & 43 & 37 & 9 & 92 & 91 & 184 \\
Piotta & 1106 & 4.94 & 10.7 & 11 & 21 & 11 & 3 & 9 & 1 & n.d. & 23 & 24 & 10 & 57 & 56 & 113 \\
Acquarossa & 984 & 5.03 & 9.6 & 9 & 22 & 12 & 4 & 5 & 2 & n.d. & 23 & 23 & 8 & 54 & 53 & 107 \\
Stabio & 1170 & 4.93 & 16.9 & 12 & 49 & 20 & 6 & 8 & 1 & 3 & 45 & 40 & 8 & 96 & 96 & 191 \\
Robiei & 1967 & 4.91 & 8.2 & 12 & 15 & 10 & 2 & 3 & 1 & n.d. & 21 & 15 & 3 & 44 & 38 & 82 \\
Monte Bré & 1007 & 4.86 & 14.4 & 14 & 37 & 15 & 5 & 6 & 1 & n.d. & 37 & 35 & 7 & 77 & 79 & 157 \\
\hline
\end{tabular}

Tab. 5. Mean concentrations (1997) of the main chemical variables in the rivers considered.

\begin{tabular}{|c|c|c|c|c|c|c|c|c|}
\hline & $\mathrm{pH}$ & $\begin{array}{c}\text { Cond. } \\
\left(\mu \mathrm{S} \mathrm{cm}^{-1} 20^{\circ} \mathrm{C}\right)\end{array}$ & 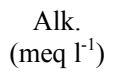 & $\begin{array}{c}\mathrm{NH}_{4}^{+} \\
\left(\mathrm{mmol} \mathrm{l}^{-1}\right)\end{array}$ & $\begin{array}{c}\mathrm{NO}_{3}^{-} \\
\left(\mathrm{mmol} \mathrm{l}^{-1}\right)\end{array}$ & $\begin{array}{c}\mathrm{TN} \\
\left(\mathrm{mmol} \mathrm{l}^{-1}\right)\end{array}$ & $\begin{array}{c}\mathrm{RP} \\
\left(\mu \mathrm{mol} \mathrm{l}{ }^{-1}\right)\end{array}$ & $\begin{array}{c}\mathrm{TP} \\
\left(\mu \mathrm{mol} \mathrm{l^{-1 }}\right)\end{array}$ \\
\hline Ticino inlet & 7.86 & 259 & 1.05 & $<0.01$ & 0.06 & 0.07 & 0.16 & 0.29 \\
\hline Maggia & 7.79 & 72 & 0.47 & $<0.01$ & 0.06 & 0.07 & 0.13 & 0.23 \\
\hline Cannobino & 7.40 & 41 & 0.21 & $<0.01$ & 0.05 & 0.06 & 0.13 & 0.19 \\
\hline S. Giovanni & 7.24 & 45 & 0.16 & $<0.01$ & 0.08 & 0.09 & 0.14 & 0.24 \\
\hline S. Bernardino & 7.45 & 70 & 0.34 & $<0.01$ & 0.09 & 0.10 & 0.11 & 0.18 \\
\hline Toce & 7.52 & 174 & 0.80 & $<0.01$ & 0.04 & 0.06 & 0.58 & 0.77 \\
\hline Pellino & 7.25 & 48 & 0.21 & $<0.01$ & 0.11 & 0.12 & 0.29 & 0.45 \\
\hline Pellesino & 7.25 & 44 & 0.17 & $<0.01$ & 0.11 & 0.13 & 0.90 & 1.26 \\
\hline Pescone & 7.31 & 60 & 0.21 & $<0.01$ & 0.12 & 0.15 & 0.94 & 0.84 \\
\hline Erno & 7.41 & 106 & 0.34 & $<0.01$ & 0.12 & 0.13 & 0.44 & 0.64 \\
\hline Vevera & 7.84 & 219 & 1.71 & 0.01 & 0.21 & 0.25 & 1.15 & 1.60 \\
\hline Bardello & 8.04 & 407 & 2.91 & 0.02 & 0.14 & 0.23 & 3.97 & 5.65 \\
\hline Boesio & 8.00 & 672 & 5.54 & 0.05 & 0.17 & 0.34 & 7.17 & 11.21 \\
\hline Tresa & 8.28 & 203 & 1.77 & 0.01 & 0.07 & 0.11 & 0.68 & 1.49 \\
\hline Ticino outlet & 8.23 & 139 & 0.78 & 0.00 & 0.05 & 0.07 & 0.12 & 0.42 \\
\hline
\end{tabular}

considerably below the $1978-95$ average $\left(313 \mathrm{~m}^{3} \mathrm{~s}^{-1}\right)$. In 1996 the maximum discharge was recorded in July $(870$ $\left.\mathrm{m}^{3} \mathrm{~s}^{-1}\right)$; the mean value was $265 \mathrm{~m}^{3} \mathrm{~s}^{-1}$, as a consequence of the higher precipitation volume.

The main chemical characteristics of the atmospheric deposition collected in the 13 stations during 1997 are shown in table 4 as mean values weighted on precipitation volume. $\mathrm{pH}$ values, recalculated from mean $\mathrm{H}^{+}$concentrations, range from 4.54 (Pallanza) to 5.03 (Acquarossa). Some stations however record positive alkalinity, resulting from the episodic deposition of Saharan dust, which occurs 2-3 times a year. Acidity derives in similar proportions from nitrate $\left(15-47 \mu \mathrm{eq}^{-1}\right)$ and sulphate $\left(21-48 \mu \mathrm{eq}^{-1}\right)$. Ammonium contributes significantly to the ionic load (15-55 $\left.\mu \mathrm{eq}^{-1}\right)$, calcium concentrations are between 9 and $20 \mu$ eq $\mathrm{l}^{-1}$, while $\mathrm{Na}^{+}$, $\mathrm{Mg}^{++}, \mathrm{K}^{+}$and $\mathrm{Cl}^{-}$concentrations are very low $(<10 \mu \mathrm{eq}$ $\mathrm{l}^{-1}$ ) at all stations (Tab. 4). The total ionic content is quite variable, from about $200 \mu \mathrm{eq} \mathrm{I}^{-1}$ at the southernmost stations (Pallanza, Bellinzago and Orta) to 80-100 $\mu$ eq $1^{-1}$ at the northern ones (Acquarossa, Piotta and Robiei), with corresponding conductivity values of 20-22 and $8-10 \mu \mathrm{S} \mathrm{cm}^{-1}$, respectively.
This difference is confirmed by cluster analysis of the atmospheric deposition data. There is a sharp distinction between two groups of sampling stations: on the one hand, Robiei, Piotta, Acquarossa, Devero, Graniga and Domodossola, located in the north-western part of the catchment in the mountains, and on the other, Stabio, Lugano, Monte Brè, Lunecco, S.M. Orta, Bellinzago and Pallanza, located in the subalpine area (Fig. 1, Tab. 2). The second group of stations, being located closer to the highly polluted area of the Po Plain, is characterised by a higher pollutant content.

\subsection{Rivers}

Table 5 shows the main chemical characteristics of the Lago Maggiore tributaries and of the Ticino outlet. The rivers differ widely in ionic concentrations, as is highlighted by the conductivity values which range from 41 to $672 \mu \mathrm{S} \mathrm{cm}^{-1}$ at $20^{\circ} \mathrm{C}$, according to the geology of the catchments. Bicarbonate and calcium ions are present in the highest concentrations; bicarbonate is the main variable contributing to alkalinity, with values ranging from 0.15 to 0.30 meq $\mathrm{l}^{-1}$ for rivers with catchments where the underlying rocks are mainly igneous, 

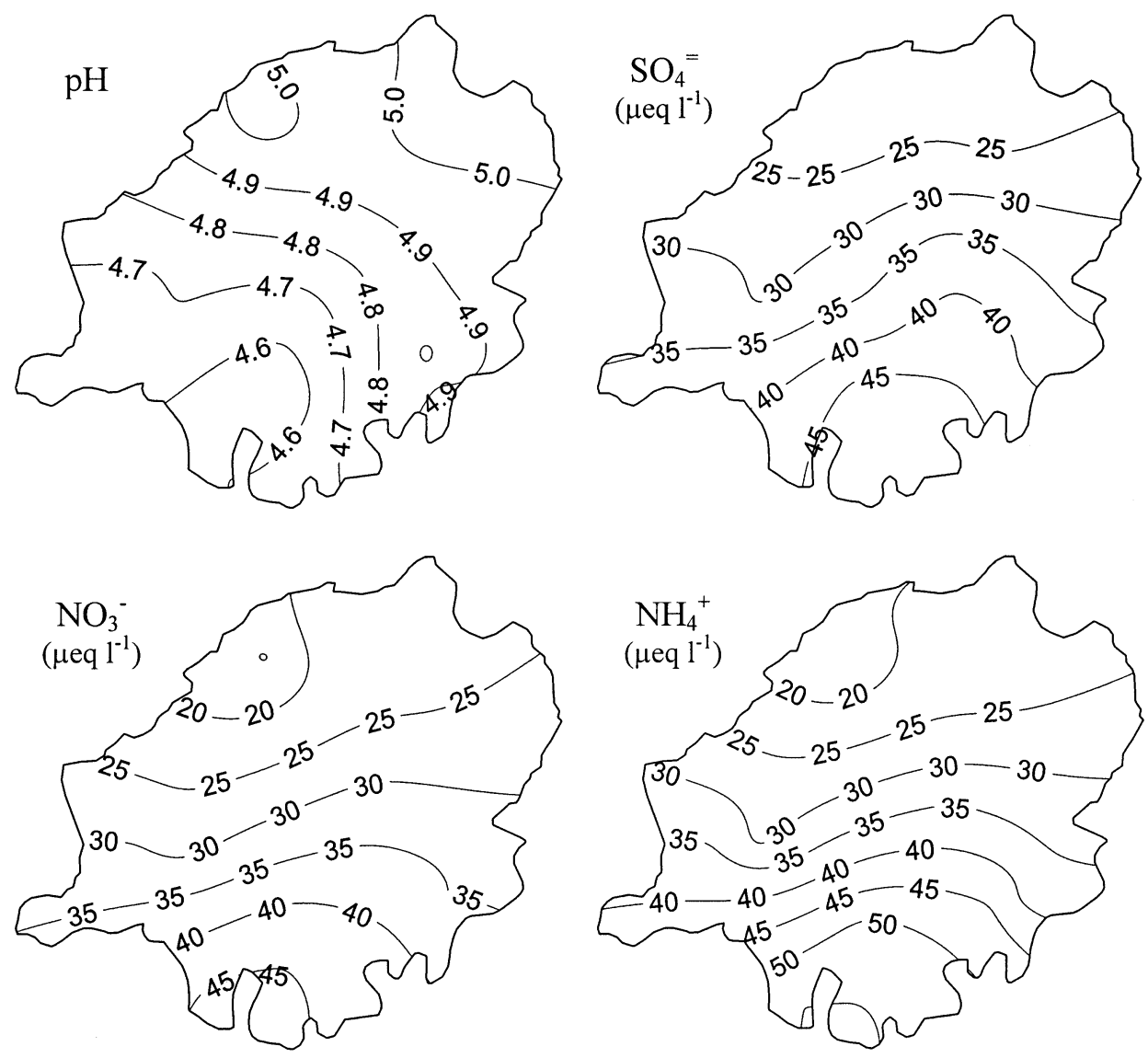

Fig. 4. Spatial distribution of $\mathrm{pH}, \mathrm{SO}_{4}{ }^{-}, \mathrm{NO}_{3}{ }^{-}$and $\mathrm{NH}_{4}{ }^{+}$wet precipitation in Lago Maggiore catchment in 1997.

to values over 1.5-3.0 meq $\mathrm{l}^{-1}$ for rivers draining calcareous catchments. The high alkalinity in the river Boesio is due to the presence of industrial activities, which produce waste water with a high bicarbonate content. $\mathrm{pH}$ values show a good relation with alkalinity, ranging from 7.2 to 8.0 , with the highest values of 8.28 and 8.23 for rivers Tresa and Ticino, the outflows of lakes Lugano and Maggiore respectively.

Ammonium concentrations are negligible in most of the rivers (exceptions are rivers Tresa, Boesio and Bardello), while nitrate varies between 40 and $210 \mu \mathrm{mol} \mathrm{l}^{-1}$ (rivers Toce and Vevera, respectively). Total nitrogen, which comprises both organic and inorganic $\mathrm{N}$, follows the same pattern as nitrate; organic nitrogen provides only a minor contribution. Some rivers (Ticino inlet, Verzasca, Maggia, Cannobino, S. Giovanni, S. Bernardino) have low concentrations both of reactive and total phosphorus (0.1-0.5 and 0.2-1.0 $\mu \mathrm{mol} \mathrm{l}^{-1}$ respectively), due to the low population density in the catchment. Phosphorus content is higher in the Lago d'Orta tributaries, the Toce and the Tresa, and very high in the River Bardello, which receives the outflowing water from the highly eutrophic Lago Varese, and the Boesio, whose catchment is affected by intense industrial activity (Tab. 5).

\section{DISCUSSION}

\subsection{Atmospheric deposition}

To get a complete pattern of the rain chemistry on the Lago Maggiore catchment, we used the annual chemical data of atmospheric deposition collected from the Italian and Swiss stations in 1997, calculating the spatial distribution of $\mathrm{pH}, \mathrm{SO}_{4}{ }^{=}, \mathrm{NO}_{3}{ }^{-}$and $\mathrm{NH}_{4}{ }^{+}$(Fig. 4). $\mathrm{pH}$ values show a clear decreasing trend, from 5.0 to 4.6, from the north-east to the south of the area. Most of the chemical variables show a similar pattern, as a consequence of local meteorological characteristics.

Precipitation in the area is mainly determined by warm, moist air masses entering the Po Valley from the Mediterranean and colliding with the Alps. The air rises and cools, which produces orographic precipitation, more intense in the subalpine area, where annual precipitation above $2000 \mathrm{~mm}$ is frequent (Carollo et al. 1985). In 1997 the total amount of precipitation on the Lago Maggiore catchment was $1417 \mathrm{~mm}$, with maximum values $(1600-1700 \mathrm{~mm})$ in the southernmost part, close to the foothills of the Alps, which stop the air masses coming from the plain (Fig. 5). The volumes then decrease towards the north to minimum values of 

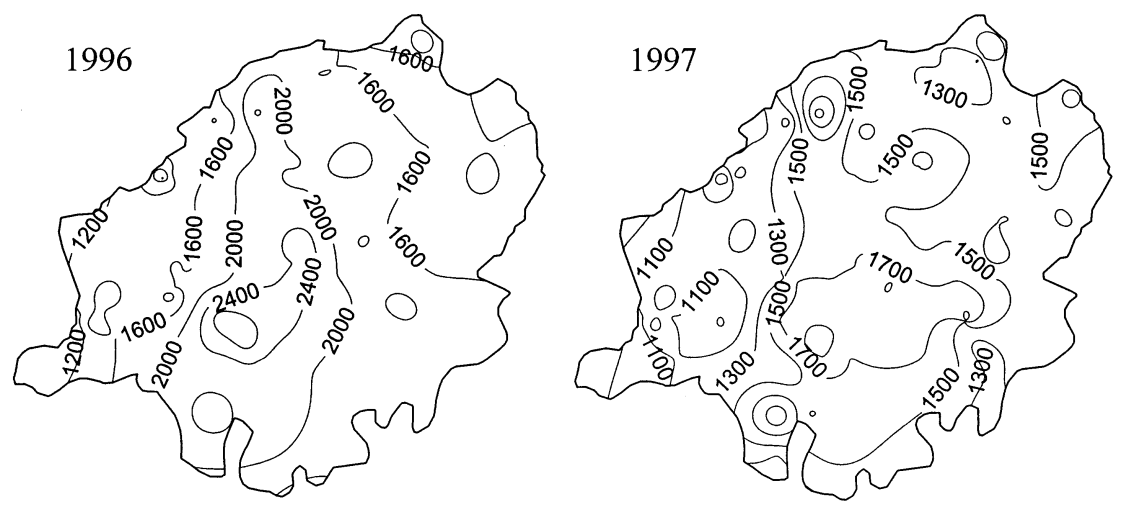

Fig. 5. Spatial distribution of the amount of precipitation (mm) at Lago Maggiore catchment in 1996 and 1997.
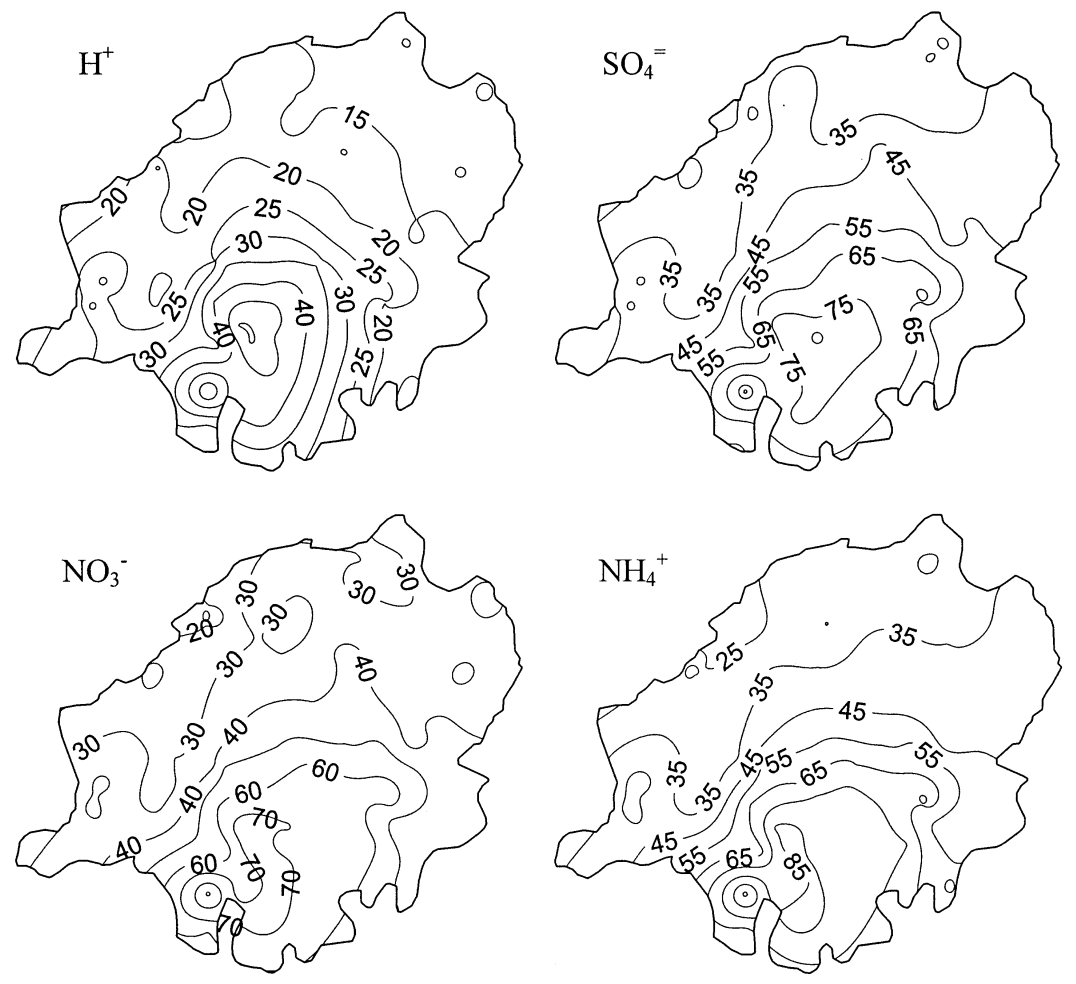

Fig. 6. Spatial distribution of $\mathrm{H}^{+}, \mathrm{SO}_{4}{ }^{=}, \mathrm{NO}_{3}{ }^{-}$and $\mathrm{NH}_{4}{ }^{+}$fluxes in wet deposition (meq $\mathrm{m}^{-2} \mathrm{y}^{-1}$ ) in Lago Maggiore catchment in 1997.

900-1100 mm. This pattern is very similar to that observed in 1996 (Fig. 5), which was distinguished only by higher amounts of precipitation; the distribution of the relief determines this as the typical pattern of the area.

The sources of atmospheric pollutants are mainly located in the Po Valley, south of the Lago Maggiore catchment, so that the pollutant concentration shows a gradient with highest values in the south of the catchment and gradually decreasing towards the north. In contrast with the regular gradient of the ionic concentrations, the spatial distribution of the amount of precipitation is irregular, with local maxima near the south- ernmost topographic highs. This pattern is also present in long-term meteorological series (e.g. 50 years, Carollo et al. 1985) and leads to an irregular distribution of ionic fluxes within the Lago Maggiore catchment (Fig. $6)$. The range of values is quite wide in the case of $\mathrm{H}^{+}$ (from $60-70 \mathrm{mmol} \mathrm{m}^{-2} \mathrm{y}^{-1}$ in the subalpine area to $10-15$ $\mathrm{mmol} \mathrm{m} \mathrm{y}^{-1}$ in the Alpine area). Similar gradients are also observed for the other chemical variables. (Fig. 6).

\subsection{Nitrogen load to the tributaries}

Table 6 shows the population density, the atmospheric input to each catchment and the output of nitrate and ammonium from the catchments to the lake, calcu- 
Tab. 6. Population density, input and output of nitrogen loads as ammonium, nitrate and total nitrogen in Lago Maggiore catchment in 1997. Values in meq $\mathrm{m}^{-2} \mathrm{y}^{-1} .{ }^{1)}$ Values referred to 1995 including touristic presence. ${ }^{2)}$ Input of inorganic nitrogen $\left(\mathrm{NH}_{4}+\mathrm{NO}_{3}\right)$

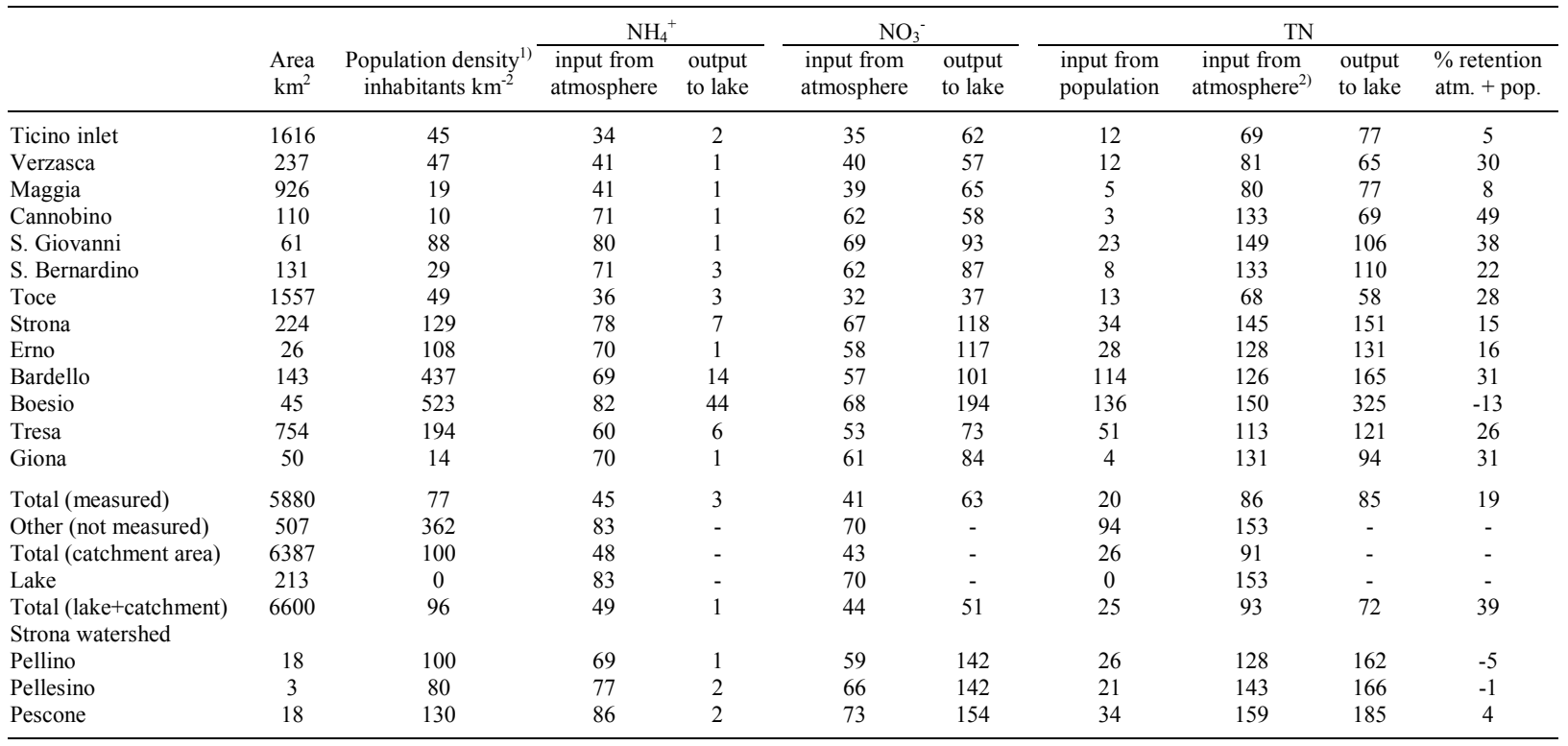

lated for the main tributaries of Lago Maggiore and for the three main tributaries of Lago d'Orta, included in the River Strona catchment (Fig. 1). The input and output of total $\mathrm{N}$ are also shown; in this case we considered as inputs the atmospheric deposition of inorganic nitrogen (sum of $\mathrm{NO}_{3}$ and $\mathrm{NH}_{4}$ ) and the input of total $\mathrm{N}$ from the population, assuming a pro-capita contribution of 10 $\mathrm{g} \mathrm{N}$ inhab ${ }^{-1}$ day $^{-1}$.

The population data refer to 1995 and include temporary residents (visitors) but not the inhabitants of the shore areas, whose domestic effluents go directly into the lake.

Nitric nitrogen is the major form, making up about $80-90 \%$ of the total nitrogen load from the rivers to the lake. The ammonium contribution is usually negligible, with the exception of the rivers Bardello and Boesio, where it is respectively 8 and $14 \%$ of total nitrogen. There is virtually no $\mathrm{NH}_{4}$ leaching, so that all incoming $\mathrm{NH}_{4}$ is either retained directly or nitrified to $\mathrm{NO}_{3}$. As a consequence of nitrification, the catchment output of $\mathrm{NO}_{3}$ is generally higher than the input from atmosphere for all the rivers except River Cannobino (Tab. 6).

A negative percent retention value of the total $\mathrm{N}$ input is found for River Boesio, which has a highly polluted catchments. Particularly interesting is the situation of the Lago d'Orta tributaries, which, in spite of the low urban or industrial discharge in their catchments, pres??ent low or negative retention values (Tab. 6).

We also considered the regression between the nitrogen loads, expressed as mmol $\mathrm{m}^{-2} \mathrm{y}^{-1}$, and the population density (1995 figures) of the catchments of the main Lago Maggiore tributaries (Fig. 7). This was statistically significant for ammonium $\left(\mathrm{R}^{2}=0.818, \mathrm{p}\right.$ $<0.0001$ ), which derives almost totally from point sources (urban and industrial sewage), and total nitrogen $\left(\mathrm{R}^{2}=0.666, \mathrm{p}<0.001\right)$. In the case of nitrate, the data are more scattered $\left(R^{2}=0.331, p<0.05\right)$ as a consequence of the higher influence of non-point sources, like atmospheric deposition.

The slope obtained from the linear regression relating to total nitrogen was used to evaluate the urban contribution to the total load. For 1997 this was $1.1 \mathrm{~mol}$ inhab $^{-1}$ day $^{-1}$ (15 $\left.\mathrm{g} \mathrm{inhab}^{-1} \mathrm{day}^{-1}\right)$, using the whole set of data, or $0.7 \mathrm{~mol} \mathrm{inhab}^{-1} \mathrm{day}^{-1}\left(10 \mathrm{~g} \mathrm{inhab}^{-1} \mathrm{day}^{-1}\right) \mathrm{ex}-$ cluding industrially polluted rivers (Strona, Boesio, Vevera) and rivers with lakes in their catchments (Bardello, Tresa). Both values are far lower than the 1978 value from the same rivers $\left(23.0 \mathrm{~g}_{\text {inhab }}{ }^{-1} \mathrm{day}^{-1}\right)$ (Mosello et al. 1978). The intercept value indicates that diffuse sources in the catchment account for a high amount of nitrogen (about $70 \mathrm{mmol} \mathrm{m}^{-2} \mathrm{y}^{-1}$ ), most of which comes from atmospheric deposition.

For the inflowing rivers (sampled catchments) the theoretical values of total input estimated by calculation $\left(10^{6} \mathrm{mmol} \mathrm{m}^{-2} \mathrm{y}^{-1}\right.$ for the total area drained by rivers, obtained as sum of population and deposition inputs; Tab. 6) were compared with the measured values of the total nitrogen load to the lake $\left(85 \mathrm{mmol} \mathrm{m}^{-2} \mathrm{y}^{-1}\right)$, deriving from the product of concentrations and water discharges. The difference which emerged was about $20 \%$; this indicates the percent retention of the total input by the river catchments. We attributed this retention wholly to atmospheric input. The content of atmospheric deposition interacts with soil and vegetation before reaching surface water and is involved in biological processes, while waste water is generally drained towards tributaries or lakes. 

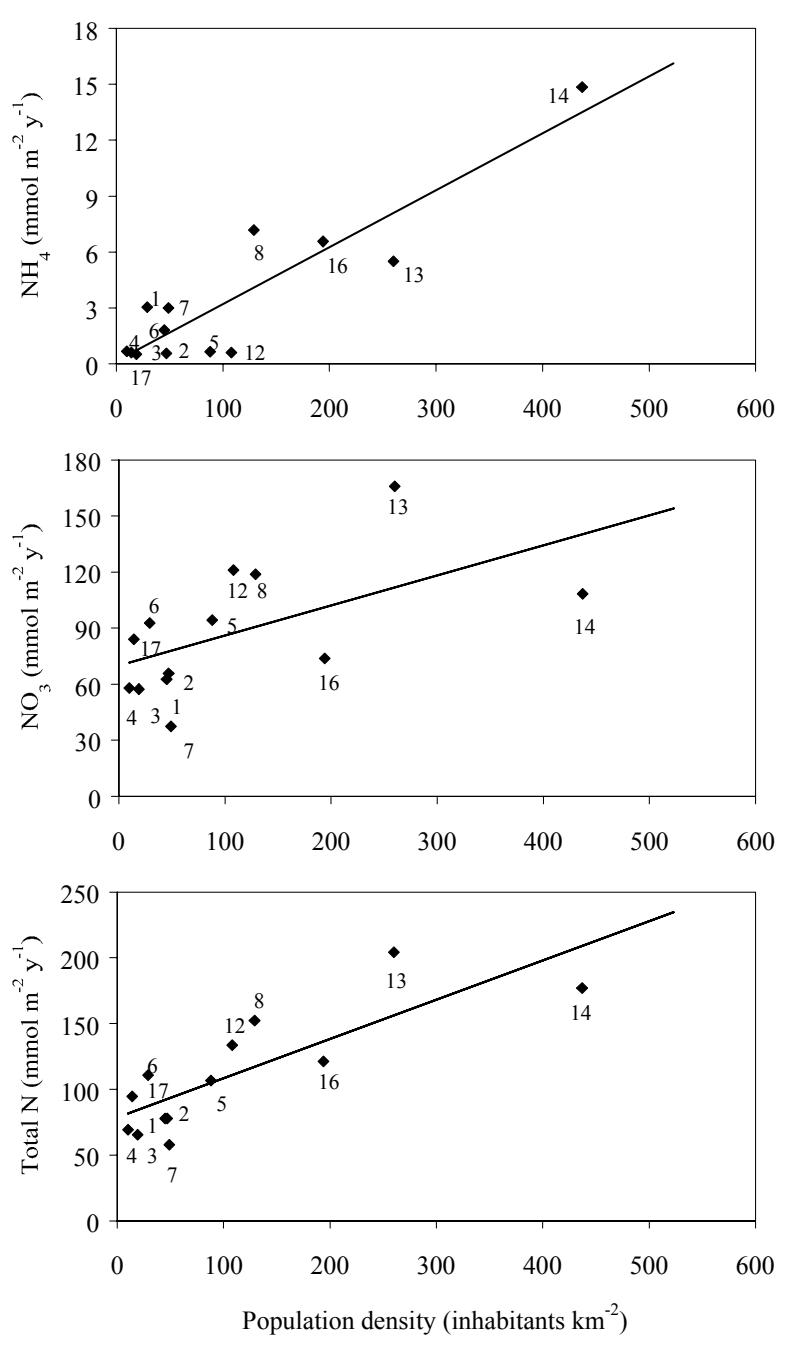

Fig. 7. Linear regression between population density and ammonium, nitrate and total nitrogen (including organic nitrogen) loads for the main Lago Maggiore tributaries in 1997. Numbers refer to table 3.

\subsection{Total nitrogen balance for Lago Maggiore}

The total nitrogen balance for Lago Maggiore (Tab. 7) was calculated for the years 1996 and 1997. Inputs are those measured at the major inflowing rivers, estimates from ungauged areas, and direct precipitation to the lake. The calculated inputs from the atmosphere to the river catchments and to the ungauged areas were corrected to take the catchment retention into account. The nitrogen load from the atmosphere to the lake surface, calculated by Kriging interpolation of the data from the various sampling stations, was about $153 \mathrm{meq}$ $\mathrm{m}^{-2} \mathrm{y}^{-1}$ in 1997 (Tab. 6) i.e. $3310^{6} \mathrm{~mol} \mathrm{~N} \mathrm{y}^{-1}$. For the ungauged areas, along the shore, the nitrogen contribution came from atmospheric deposition, calculated using the same areal contribution as for the lake, and from the population. The population density in this area, based on 1995 figures (362 inhab $\mathrm{km}^{-2}$ ), is considerably higher than the mean value for the Lago Maggiore catchment
(77 inhab $\mathrm{km}^{-2}$ ). The nitrogen input to the lake from the population was calculated on the basis of a pro-capita contribution of $10 \mathrm{~g} \mathrm{~N}$ inhab $^{-1}$ day $^{-1}$.

From these assumptions, the total nitrogen input to the lake, calculated as a mean of the two years (Tab. 7), was about $72010^{6} \mathrm{~mol} \mathrm{y}^{-1}$, of which $23 \%$ derived from the population and $77 \%$ from atmospheric deposition. The calculated atmospheric contribution is an underestimate, as it does not account for organic $\mathrm{N}$ and dry deposition. In an alpine area about $100 \mathrm{~km}$ from the catchment of Lago Maggiore, (Val Sessera), the total deposition of nitrogen, calculated from throughfall deposition in a beech stand, was $20 \%$ higher than the wet deposition (Allavena et al. 1999). Considering that most of the Lago Maggiore catchment is forested, if we apply the same correction for the dry deposition of nitrogen, the atmospheric contribution increases to about $80 \%$ of the total.

The amount leaving the lake from the outlet was 516 $10^{6} \mathrm{~mol} \mathrm{y}^{-1}$; the in-lake retention was $28 \%$ of the input, mainly due to algal uptake and sedimentation.

Denitrification is probably of minor importance in the oligotrophic Lago Maggiore, as the process is more effective in eutrophic lakes (Mengis et al. 1997a); nitrogen elimination by $\mathrm{N}_{2} \mathrm{O}$ emission was also negligible (Mengis et al. 1997b)

\section{4. $N$ saturation stages of catchments}

Following the criteria of Traaen \& Stoddard (1995), we classified the catchments of selected tributaries at different nitrogen saturation stages. The results are shown in figure 8.

Rivers Erno, Pellino and Pellesino qualify for the highest level of nitrogen saturation (stage 3), which is characterised by a nitrate concentration of over $50 \mu \mathrm{mol}$ $\mathrm{l}^{-1}$ during the growing season (March-July in the subalpine area). The other rivers show nitrate concentrations in this period slightly below $50 \mu \mathrm{mol} \mathrm{l^{-1 }}$ and may be assigned to saturation stage 2/3 (Cannobino and Maggia) or 2 (Toce) (Fig. 8).

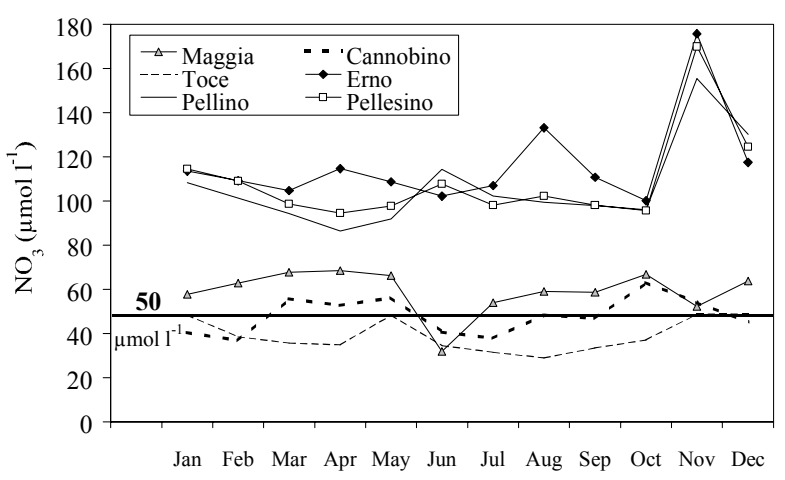

Fig. 8. Monthly nitrate concentrations measured in 1997 in some selected rivers compared with the critical level of 50 $\mu \mathrm{mol} 1^{-1}$. 
Tab. 7. Total nitrogen balance $\left(10^{6} \mathrm{~mol} \mathrm{y}^{-1}\right)$ of Lago Maggiore.

\begin{tabular}{|c|c|c|c|}
\hline & 1996 & 1997 & $1996-97$ \\
\hline $\begin{array}{l}\text { Input from catchments of monitored inflowing rivers }\left(5880 \mathbf{~ k m}^{2}\right) \\
\text { Input from atmosphere to catchments }\end{array}$ & 623 & 506 & 564 \\
\hline $\begin{array}{l}\text { Input from catchments to the lake } \\
\text { Atmosphere } \\
\text { Population }\end{array}$ & $\begin{array}{l}498 \\
118\end{array}$ & $\begin{array}{l}405 \\
118\end{array}$ & $\begin{array}{l}451 \\
118\end{array}$ \\
\hline $\begin{array}{l}\text { Input from ungauged terrestrial areas }\left(507 \mathbf{~ k m}^{2}\right) \\
\text { Input from atmosphere to ungauged areas }\end{array}$ & 91 & 78 & 84 \\
\hline $\begin{array}{l}\text { Input from ungauged areas to the lake } \\
\text { Atmosphere } \\
\text { Population }\end{array}$ & $\begin{array}{l}73 \\
48\end{array}$ & $\begin{array}{l}62 \\
48\end{array}$ & $\begin{array}{l}67 \\
48\end{array}$ \\
\hline $\begin{array}{l}\text { Direct input on the lake }\left(213 \mathbf{k m}^{2}\right) \\
\text { Atmosphere }\end{array}$ & 38 & 32 & 35 \\
\hline $\begin{array}{l}\text { Total input to the lake } \\
\text { Atmosphere } \\
\text { Population }\end{array}$ & $\begin{array}{l}609 \\
166\end{array}$ & $\begin{array}{l}499 \\
166\end{array}$ & $\begin{array}{l}553 \\
166\end{array}$ \\
\hline Total & 775 & 665 & 719 \\
\hline $\begin{array}{l}\text { Output from the lake } \\
\text { Retention \% in the lake } \\
\% \text { input (atmosphere) }\end{array}$ & $\begin{array}{l}555 \\
28 \\
79\end{array}$ & $\begin{array}{l}476 \\
28 \\
75\end{array}$ & $\begin{array}{l}516 \\
28 \\
77\end{array}$ \\
\hline
\end{tabular}

Taken together, the results from the Stoddard approach confirm the critical situation of the catchments as regards nitrogen saturation; the high atmospheric input of nitrogen compounds affecting this area cannot be retained entirely through the processes taking place in the soil and the vegetation, so that the nitrogen is leached by surface water.

\subsection{Interannual variability and long-term trend}

As there are inevitably meteorological and hydrological differences from year to year, we calculated the total nitrogen balance for 1996 as well, to get a more comprehensive evaluation of the different sources of nitrogen. Hydrologically, the two years were significantly different, with precipitation higher in 1996 than in 1997 (Fig. 5). The total input of nitrogen from the atmosphere, including the input of the rivers and precipitation on the ungauged area and the lake, was about $49010^{6}$ moles in 1997, against $61510^{6}$ moles in 1996 (Tab. 7). The output, through the Ticino outlet, was also higher in 1997 (555 10 moles) than in 1996 (476 10 moles). The calculated \% retention is very similar for both years (26 and 24\% respectively).

Interannual variability can also be evaluated by plotting the yearly amounts of precipitation for the whole Lago Maggiore catchment against its total nitrogen $\left(\mathrm{NH}_{4}^{+}+\mathrm{NO}_{3}^{-}\right)$input from rivers and direct precipitation. The correlation $\left(n=21 ; \mathrm{R}^{2}=0.629\right)$ between these two variables (Fig. 9), highlights the important role of atmospheric deposition in the nitrogen load to the lake. The positions of years 1996 and 1997 are representative of medium-high and low values of precipitation, respectively.

Nitrate concentrations in Lago Maggiore, increased markedly between 1956 and 1978, from about 40 to 57 $\mu \mathrm{mol} \mathrm{l}{ }^{-1}$, and then remained fairly constant or increased only slightly in the following years (1979-98) (Fig. 10) (Mosello et al. 2000b; Ambrosetti et al. 1992). Total nitrogen concentrations have increased slowly, recently reaching values of 67-68 $\mu \mathrm{mol} \mathrm{l}^{-1}$ (Fig. 10).

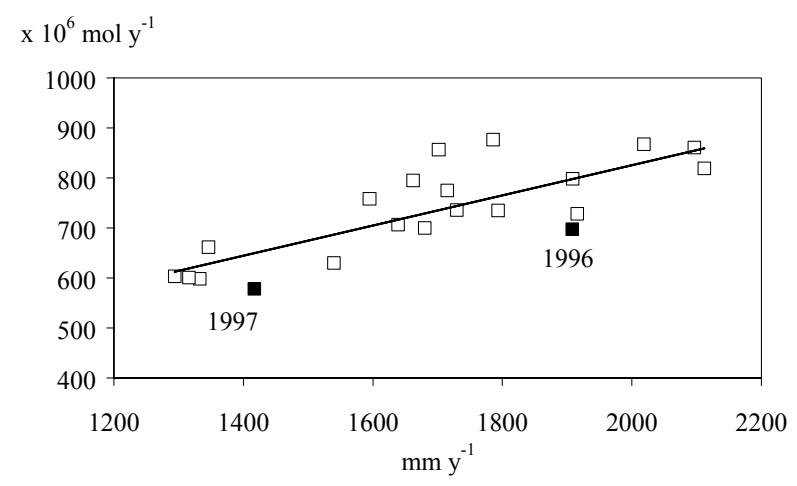

Fig. 9. Linear regression between the yearly precipitation on Lago Maggiore catchment and the total nitrogen input in the different years of the period 1978-98. Black squares indicate years 1996 and 1997.

The high impact of atmospheric input on in-lake $\mathrm{N}$ concentrations is also evident if we compare Lago Maggiore with Lago di Como and Lago d'Iseo; their catchments, the three most important in Northern Italy, are located north of the Po Valley and have analogous meteorological patterns. The three lakes show marked increases in nitrate concentrations beginning in the 1960s (Fig. 10). The sharp decrease observed since 1994 in Lago d'Iseo is related to the establishment of anoxic conditions in the water layer below $150 \mathrm{~m}$ (Garibaldi et al. 1999). The role of the atmospheric nitrogen input may also be important in the deep subalpine lakes to the 
north of the Alps, which showed sharp increases in nitrate in the 1960s and 1970s (Mengis et al. 1997a).

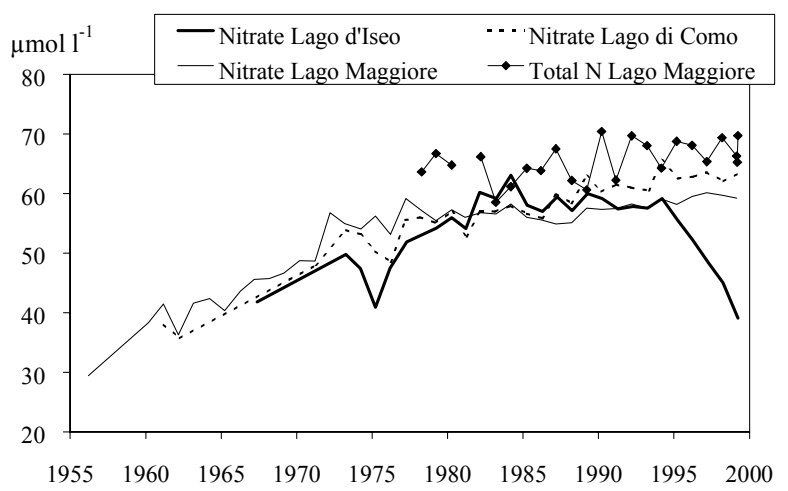

Fig. 10. Trend of nitrate in Lago Maggiore, Lago di Como and Lago d'Iseo and of total nitrogen (organic nitrogen included) in Lago Maggiore. Concentrations measured at spring water mixing.

These long-term trends can be explained by longterm trends in the atmospheric deposition of nitrogen. Precipitation has been sampled since 1975 at the sampling station of Pallanza and since 1981 at several other sites in the Lago Maggiore catchment. At Pallanza, nitrate concentrations increased from 1975-76 to 1990, with a steeper increase in the late eighties. On the other hand, ammonium concentrations showed no trend (Mosello et al. 2000a). These variations are in agreement with the values of anthropogenic emissions in Italy, as reported by the EMEP network, in the framework of the CORINAIR project (EMEP/CORINAIR 1996). $\mathrm{NH}_{3}$ emissions remained fairly constant and $\mathrm{NO}_{\mathrm{x}}$ increased slightly in the second half of the eighties.

The estimations of the annual total inputs and outputs of nitrogen to the lake, which have been available since 1978 (Fig. 11), do not show any significant trend; the interannual variations are largely attributable to variations in precipitation and discharge.

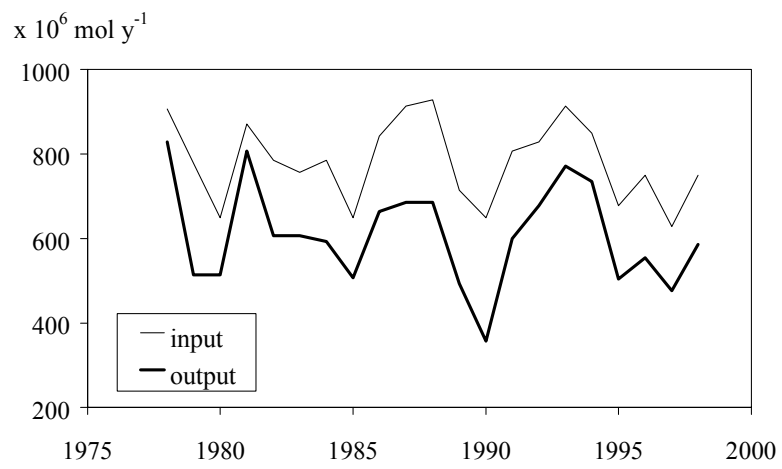

Fig. 11.Total annual inputs and outputs of nitrogen to the lake in the period 1978-98.

\subsection{Relationship between $N$ load and lake concentration}

The marked increase of nitrogen concentrations in Lago Maggiore clearly indicates that there has been an increase in the nitrogen load in the last decades. Two interesting questions on the relationship between nitrogen load and in-lake concentration may be posed: 1) is the present concentration in the lake water in equilibrium with the present nitrogen load? 2) is it possible to infer what the nitrogen load was in the past, i.e. in the fifties or earlier?

We used a mass balance approach, taking into account the total nitrogen load and the lake output via the outlet and sedimentation, as proposed for phosphorus by Imboden \& Lerman (1978) and Imboden (in Saas 1989).

The model evaluates the steady-state concentration as:

$$
\mathrm{TN}=\left(\mathrm{Q}_{\mathrm{i}} \times \mathrm{TN}_{\mathrm{i}}\right) /\left(\mathrm{Q}_{\mathrm{i}} \times \beta+\sigma \mathrm{V}\right)
$$

Where:

- $\mathrm{Q}_{\mathrm{i}}$ : inflowing water volume $\left(\mathrm{m}^{3} \mathrm{y}^{-1}\right)$, assumed as equal to the outflowing water volume;

- $\mathrm{TN}_{\mathrm{i}}$ : mean concentration of total nitrogen in inflowing water $\left(\mathrm{mmol} \mathrm{m}^{-3}\right)$;

- $\quad \beta$ : stratification factor (dimensionless), ratio between TN concentration in epilimnion and mean in lake TN concentration $\left(\mathrm{TN}_{\mathrm{i}}\right)$;

- $\sigma$ : apparent settling rate $\left(\mathrm{y}^{-1}\right)$, ratio between the amount of nitrogen yearly stored in the sediment and the mass of TN in the lake volume $\mathrm{V}\left(\mathrm{m}^{3}\right)$.

The model assumes no loss or uptake of nitrogen from the atmosphere. Detailed studies on $\mathrm{N}_{2}$ and $\mathrm{N}_{2} \mathrm{O}$ emissions from eight subalpine lakes, including Lago Maggiore (Mengis 1996), indicate that $\mathrm{N}$ loss or uptake is negligible.

The values of the different variables included in the model used for Lago Maggiore are summarised in table 8; they are obtained from the mean values of the yearly $\mathrm{N}$ budgets (period 1978-98) and from lake measurements (Mosello \& Ruggiu 1983; Calderoni \& Mosello 1989). The equilibrium concentrations of total nitrogen $\left(\mathrm{TN}_{\mathrm{eq}}\right)$, with the present load, were $70 \mathrm{mmol} \mathrm{m}^{-3}$, slightly higher than the present value $\left(\mathrm{TN}_{\mathrm{i}}\right)$ of $65 \mathrm{mmol}$ $\mathrm{m}^{-3}$. This indicates that no sharp increase in TN concentrations is expected in the next few years, and it explains the flattening of nitrate and $\mathrm{TN}$ concentrations in the last decade.

The $\mathrm{N}$ load in the fifties may be estimated from the measured nitrate concentration $\left(29 \mathrm{mmol} \mathrm{m}^{-3}\right.$ in 1955 , archives of the Istituto Italiano di Idrobiologia), assumed as a measure of TN concentration, and by applying a slightly higher stratification factor than the present one (0.99 instead of 0.97$)$, because of the lower productivity of the lake at that time, and $\mathrm{N}$ apparent settling rates between 0.06 and $0.08 \mathrm{y}^{-1}$, versus the present value of $0.07 \mathrm{y}^{-1}$ (Tab. 8). The calculated values of $\mathrm{TN}_{\mathrm{i}}$ 
Tab. 8. Variables included in the mass balance model for nitrogen applied to Lago Maggiore. Calculated values are shown in bold.

\begin{tabular}{lcccccc}
\hline & & $1978-98$ & \multicolumn{2}{c}{$1950-60$} & \multicolumn{2}{c}{ Beginning $20^{\text {th }}$ Century } \\
\hline $\mathrm{Q}_{\mathrm{i}}$ & $\mathrm{m}^{3}$ & $8.95 \mathrm{E}+09$ & $8.95 \mathrm{E}+09$ & $8.95 \mathrm{E}+09$ & $8.95 \mathrm{E}+09$ & $8.95 \mathrm{E}+09$ \\
$\mathrm{TN}_{\mathrm{i}}$ & $\mathrm{mmol} \mathrm{m}^{-3}$ & 88 & $\mathbf{3 5}$ & $\mathbf{3 8}$ & $\mathbf{1 7}$ & $\mathbf{1 9}$ \\
$\beta$ & & 0.97 & 0.99 & 0.99 & 0.99 & 0.99 \\
$\sigma$ & $\mathrm{y}^{-1}$ & 0.07 & 0.06 & 0.08 & 0.06 & 0.08 \\
$\mathrm{~V}$ & $\mathrm{~m}^{3}$ & $3.75 \mathrm{E}+10$ & $3.75 \mathrm{E}+10$ & $3.75 \mathrm{E}+10$ & $3.75 \mathrm{E}+10$ & $3.75 \mathrm{E}+10$ \\
$\mathrm{TN}_{\mathrm{l}}$ & $\mathrm{mmol} \mathrm{m}^{-3}$ & 66 & 29 & 29 & 14 & 14 \\
$\mathrm{TN}_{\mathrm{eq}}$ & $\mathrm{mmol} \mathrm{m}^{-3}$ & $\mathbf{7 0}$ & & & & \\
\hline
\end{tabular}

ranged between 35 and $38 \mathrm{mmol} \mathrm{m}^{-3}$, with a corresponding TN load between 315 and $33610^{6} \mathrm{~mol} \mathrm{y}^{-1}$, while the amount of $\mathrm{N}$ leaving the lake through the outlet was $25610^{6} \mathrm{~mol} \mathrm{y}^{-1}$.

In the first decades of the $20^{\text {th }}$ century, lower $\mathrm{N}$ concentrations should have been the rule. On analogy with values found in freshwater in pristine areas (Tartari et al. 1998) we can assume a possible in-lake total $\mathrm{N}$ level of about $14 \mathrm{mmol} \mathrm{m}^{-3}$, which would give estimated values of $\mathrm{TN}_{\mathrm{i}}$ of 17-18 $\mathrm{mmol} \mathrm{m}^{-3}\left(\mathrm{~N}\right.$ load of 154-165 $10^{6}$ $\mathrm{mol} \mathrm{y}^{-1}$ ) and a $\mathrm{N}$ output of $12510^{6} \mathrm{~mol} \mathrm{y}^{-1}$ (Tab. 8).

\section{CONCLUSIONS}

Atmospheric deposition of $\mathrm{NH}_{4}$ and $\mathrm{NO}_{3}$ appears to be of overwhelming importance in determining the $\mathrm{N}$ levels in rivers in the catchment of Lago Maggiore and in the lake itself. In 1996 and 1997, 79\% and 75\% respectively of the nitrogen reaching Lago Maggiore came from the atmosphere through deposition. These values are probably higher due to an unknown amount of deposition. The geographical pattern of deposition is influenced by the sources of atmospheric pollutants, which are mainly located in the Po Valley south of the Lago Maggiore catchment, and by local meteorology. The southern part of the Lago Maggiore catchment receives the highest deposition of nitrogen from the atmosphere, both as ammonium and nitrate; deposition of nitrogen, as of other anthropogenic compounds, gradually decreases towards the north.

Soils and vegetation in the catchment constitute a sink for $\mathrm{N}$, which is more effective in the northern part of the catchment, where the atmospheric $\mathrm{N}$ load and the density of population and industrial activity are lower. Nitrogen retention is lower in the catchments of the southern tributaries than in those in the north. In some cases, such as the catchment of Lago d'Orta, nitrate is apparently leached from the soil, as the amount of $\mathrm{N}$ leaving the catchment is higher than the atmospheric inputs. This may be an artefact due to underestimation of the atmospheric load, as dry deposition of $\mathrm{N}$ is not considered; on the other hand, cases of net nitrogen leaching in highly polluted situations have been described (Stoddard \& Traaen 1994). In the central and northern part of the Lago Maggiore catchment, where population density is low, retention of between $40 \%$ and $60 \%$ of the atmospheric input is common. Nevertheless, the soil in these catchments also shows that there is already a high level of $\mathrm{N}$ saturation, as indicated by the approach of Traaen \& Stoddard (1995).

In-lake nitrate concentrations, available since the 1950 s, clearly indicate a gradual increase, which was steepest in the 1960s and 1970s: pristine levels in Lago Maggiore were very low. The observed trend of nitrate is related to that of atmospheric deposition, which showed an increase in the second half of the 1970s, while values remained stable in the 1980s and 1990s (Mosello et al. 2000a). The $\mathrm{N}$ contribution from urban sewage and industrial activities has remained constant or decreased, due to the construction of sewage treatment plants and the implementation of stricter laws regulating industrial effluents.

The impact on freshwater of the atmospheric contribution to the nitrogen cycle in the Alpine and subalpine areas appears to be underestimated as an environmental problem.

Finally it should be remembered that the atmospheric nitrogen of the Po Valley, together with the even larger amounts of nitrogen used as fertilisers in the same area, reaches the Adriatic Sea via the Po River, with environmental effects on the coastal waters which are not yet completely understood (Paerl \& Whitall 1999, Camusso et al. 1998; Pettine et al. 1998).

It will be clear from these observations that a major reduction in atmospheric nitrogen emissions is essential if there is to be any reversal of the trend which has produced a chronic, and increasing, $\mathrm{N}$ saturation of soil and waters in Northern Italy.

\section{ACKNOWLEDGMENTS}

We thank Dr. R. Wright of the Norwegian Institute for Water Research (Oslo) and Prof. B. Wehrli of the EAWAG, Limnological Research Center (Kastanienbaum, Switzerland) for their critical reading of the paper. 


\section{REFERENCES}

Aber, J.D., K.J. Nadelhoffer, P. Steudler \& J. Melillo. 1989. Nitrogen saturation in northern forest ecosystem. Bioscience, 39: 378-386.

Allavena, S., R. Isopi, B. Petriccione \& E. Pompei. 1999. Programma nazionale integrato per il controllo degli ecosistemi forestali. Ministero per le Politiche Agricole. Direzione generale delle risorse forestali, montane ed idriche. Corpo Forestale dello Stato: $167 \mathrm{pp}$.

Ambrosetti, W., L. Barbanti, R. Mosello \& A. Pugnetti. 1992. Limnological studies on the deep southern alpine lakes Maggiore, Lugano, Como, Iseo and Garda. Mem. Ist. ital. Idrobiol., 50: 117-146.

Bertoni, R., A. Calderoni, R. de Bernardi \& R. Mosello. 1998. Chimismo delle acque ed evoluzione trofica. In: C.N.R. Istituto Italiano di Idrobiologia (Ed.), Ricerche sull'evoluzione del Lago Maggiore. Aspetti limnologici. Programma quinquennale 1993-1997. Campagna 1997 e Relazione finale. Ed. Commissione Inter. per la protezione delle acque italo-svizzere: $60-65$.

Boggero, A., S. Belfanti, M.C. Brizzio, A. Calderoni \& R. Mosello. 1996. Trends in the chemistry of surface water in north-western Italy. IV. Nitrogen in subalpine rivers Pellino, Pellesino, Pescone and Cannobino (Lago Maggiore watershed). Mem. Ist. ital. Idrobiol., 54: 143-160.

Calderoni, A. \& R. Mosello. 1989. Apporti di nutrienti ed evoluzione delle caratteristiche chimiche delle acque lacustri. In: C.N.R. Istituto Italiano di Idrobiologia (Ed.), Rapporto quinquennale 1983-1987 sulle ricerche relative al bacino del Lago Maggiore. Commissione internazionale per la protezione delle acque italo-svizzere: 51-64.

Camusso, M., M. Bonacina \& M. Pettine. 1998. Reassessment of element fluxes to the Adriatic sea from the River Po. Fresenius Envir. Bull., 7: 51-59.

Carollo, A., F. Contardi, V. Libera \& A. Rolla. 1985. Hydroclimatic cartography of the Lake Maggiore drainage basin. Mem. Ist. ital. Idrobiol., 46: 21-40.

EMEP/CORINAIR. 1996. Atmospheric emission inventory guidebook. European Environment Agency, February 1996.

Garibaldi, L., V. Mezzanotte, M.C. Brizzio, M. Logora \& R. Mosello. 1999. The trophic evolution of Lake Iseo as related to its holomixis. J. Limnol., 58(1): 10-19.

Imboden, D.M. \& A. Lerman. 1978. Chemical models of lakes. In: Lerman, A. (Ed.), Lakes: chemistry, Geology, Physics. Springer, New York: 341-356.

Lükewille A., D. Jeffries, M. Johannessen, G. Raddum, J. Stoddard \& T. Traaen. 1997. Transboundary Air Pollution. International Cooperative Programme on Assessment and Monitoring of Acidification of Rivers and Lakes. The nine year report: acidification of surface water in Europe and North America - Long-term developments (1980s and 1990s). NIVA-report n ${ }^{\circ}$ 3637-97:168 pp.

Marchetto, A., A. Boggero, M.C. Brizzio, R. Mosello \& A Barbieri. 1998. Nitrogen content in atmospheric deposition and headwater lakes in the Lake Maggiore drainage basin In: Tappeiner, U., F.V. Ruffini \& M. Fumai (Eds), Hydrology, Water Resources and Ecology of Mountain Areas. Proc. HeadWater '98 Conference, Meran/Merano (Italy), 20-23 April 1998: 218-221.

Marchetto, A., R. Mosello, R. Psenner, G. Bendetta, A. Boggero, D. Tait \& G.A. Tartari. 1995. Factors affecting water chemistry of alpine lakes. Aquat. Sci., 55: 81-89.

Mengis, M. 1996. Nitrogen elimination in lakes by $\mathrm{N}_{2}$ and $\mathrm{N}_{2} \mathrm{O}$ emission. Dissertation ETH Nr. 11927, Luzerne: 96 pp.

Mengis, M., R. Gächter, \& B. Wehrli. 1997a. Recent trends of nitrogen elimination in Swiss lakes. Gas Wasser Abwasser, 77: 174-180.
Mengis, M., R. Gächter, \& B. Wehrli. 1997b. Sources and sinks of nitrous oxide $\left(\mathrm{N}_{2} \mathrm{O}\right)$ in deep lakes. Biogeochemistry, 38: 281-301.

Mosello, R. \& De Giuli, E. 1982. Methods of calculation of chemical loads as applied to Lake Maggiore. Mem. Ist. ital Idrobiol., 40: 55-77.

Mosello, R. \& D. Ruggiu. 1983. Apporti e concentrazioni di nutrienti, fitoplancton e livello trofico del Lago Maggiore. In: C.N.R. Istituto Italiano di Idrobiologia (Ed.), Rapporto quinquennale 1978-1983 sulle ricerche relative al bacino del Lago Maggiore. Commissione internazionale per la protezione delle acque italo-svizzere: 39-64.

Mosello, R., A. Calderoni \& E. de Giuli. 1978. Bilancio chimico del Lago Maggiore nel 1978. Mem. Ist. ital. Idrobiol., 39: 7-29.

Mosello, R., A. Marchetto \& R. Bettinetti. 2000b. Lo studio delle acque nel prossimo Millennio: problemi e prospettive. Acqua Aria, 1: 93-103.

Mosello, R., M. Della Lucia, A. Marchetto \& G.A. Tartari. 1993a. Trends in the chemistry of surface water in Northwestern Italy. I. Atmospheric deposition. Mem. Ist. ital. Idrobiol., 51: 147-165.

Mosello, R., M.C. Brizzio, A. Calderoni, A. Marchetto \& G.A. Tartari. 1993b. Trends in the chemistry of surface water in north-western Italy. II. Watershed budget and trends in River Cannobino. Mem. Ist. ital. Idrobiol., 51: 167-184.

Mosello, R., A. Marchetto, M.C. Brizzio, M. Rogora \& G.A. Tartari. 2000a. Results from the Italian participation in the International Co-operative Programme on Assessment and Monitoring of Acidification of Rivers and Lakes (ICP Waters). J. Limnol., 59: 47-54.

Mosello, R., A. Barbieri, G. Bendetta, A. Boggero, A. Marchetto, R. Psenner, D. Tait \& G.A. Tartari. 1993c. Quantification of the susceptibility of alpine lakes to acidification. Mem. Ist. ital. Idrobiol., 52: 355-386.

Mosello, R., M. Bianchi, M.C. Brizzio, H. Geiss, W. Leyendecker, A. Marchetto, D. Rembges, G.A. Tartari \& H. Muntau. 1998. AQUACON-MedBas Subproject No. 6. Acid rain analysis. Intercomparison 1/98. Joint Res. Centre European Commission, Rep. EUR 19015 EN: 81 pp.

Paerl, H.W. \& D.R. Whitall. 1999. Anthropogenically-derived atmospheric nitrogen deposition, marine eutrophication and harmful algal blooms expansion: is there a link? Ambio, 28: 307-311.

Pettine, M., L. Patrolecco, M. Camusso \& S. Crescenzio. 1998. Transport of carbon and nitrogen to the northern Adriatic Sea by the Po River. Estuarine, Coastal and Shelf Science, 46: 127-142.

Saas, H. 1989. Lake restoration by reduction of nutrient loading: expectations, experiences, extrapolation/coordination. Academia Verlag., Richarz: 497 pp.

Stoddard, J. \& T. Traaen. 1994. The stages of nitrogen saturation: classification of catchments included in "ICP on Waters". In: M. Hornung, M.A. Stutton and R.B. Wilson (Eds), Mapping and modelling of critical loads for nitrogen: a workshop report. Proceedings of a workshop held in Grange-over-sands (UK), 24-26 October 1994: 69-76.

Stoddard, J. L., D.S. Jeffries, A. Lükewille, T.A. Clair, P.J. Dillon, C.T. Driscoll, M. Forsius, M. Johannessen, J. SKahl, J.H. Kellogg, A. Kemp, J. Mannio, D. Monteith, P.S. Murdoch, S. Patrick, A. Rebsdorf, B.L. Skjelkvåle, M.P. Stainton, T.S. Traaen, H. van Dam, K.E. Webster, J. Wieting \& A. Wilander. 1999. Regional trends in aquatic recovery from acidification in North America and Europe 1980-95. Nature, 401: 575-578.

Tartari G.A. \& Mosello R. 1997. Metodologie analitiche e controlli di qualità nel laboratorio chimico dell'Istituto Italiano di Idrobiologia. Documenta Ist. ital. Idrobiol., 60: $160 \mathrm{pp}$. 
Tartari, G.A., G. Tartari \& R. Mosello. 1998. Water chemistry of high altitude lakes in the Khumbu Valley (Nepalese Himalayas). Mem. Ist. ital. Idrobiol., 57: 51-76.

Traaen, T.S. \& J.L. Stoddard. 1995. An assessment of nitrogen leaching from watershed included in ICP on Waters. NIVA Report 86001-3201: 39 pp.

Received: December 2000

Accepted: February 2001
Tyrell, T. 1999. The relative influences of nitrogen and phosphorus on oceanic primary production. Nature, 400: 525531. 